\title{
Review \\ A Challenge for Allergologist: Application of Allergy Diagnostic Methods in Mast Cell Disorders
}

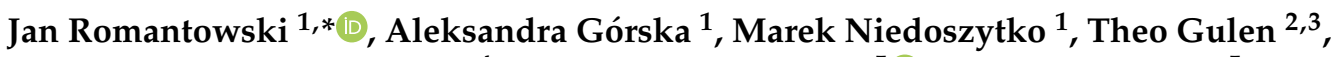 \\ Marta Gruchała-Niedoszytko ${ }^{4}$, Bogusław Nedoszytko ${ }^{5}{ }^{(D}$, Magdalena Lange ${ }^{5}$, Knut Brockow ${ }^{6}$, \\ Michel Arock ${ }^{7}{ }^{D}$, Cem Akin ${ }^{8}$ and Peter Valent ${ }^{9,10}{ }_{\mathbb{D}}$
}

check for updates

Citation: Romantowski, J.; Górska, A.; Niedoszytko, M.; Gulen, T.; Gruchała-Niedoszytko, M.; Nedoszytko, B.; Lange, M.; Brockow, K.; Arock, M.; Akin, C.; et al. A Challenge for Allergologist: Application of Allergy Diagnostic Methods in Mast Cell Disorders. Int. J. Mol. Sci. 2021, 22, 1454. https:// doi.org/10.3390/ijms22031454

Academic Editor: Yoshinori Nagai Received: 23 December 2020

Accepted: 28 January 2021

Published: 1 February 2021

Publisher's Note: MDPI stays neutral with regard to jurisdictional claims in published maps and institutional affiliations.

Copyright: (c) 2021 by the authors. Licensee MDPI, Basel, Switzerland. This article is an open access article distributed under the terms and conditions of the Creative Commons Attribution (CC BY) license (https:/ / creativecommons.org/licenses/by/ $4.0 /)$.
1 Department of Allergology, Medical University of Gdansk, 80-211 Gdańsk, Poland; klinika.alergologii@gumed.edu.pl (A.G.); mnied@gumed.edu.pl (M.N.)

2 Department of Respiratory Medicine and Allergy, Karolinska University Hospital, 14186 Huddinge, Sweden; theo.gulen@sll.se

3 Immunology and Allergy Unit, Department of Medicine Solna, Karolinska Institutet, 17177 Stockholm, Sweden

4 Department of Clinical Nutrition, Medical University of Gdansk, 80-211 Gdańsk, Poland; marta.gruchala-niedoszytko@gumed.edu.pl

5 Department of Dermatology, Venerology and Allergology, Medical University of Gdansk, 80-211 Gdańsk, Poland; bned@gumed.edu.pl (B.N.); m.lange@gumed.edu.pl (M.L.)

6 Department of Dermatology and Allergy, School of Medicine, Technical University of Munich, D-80802 Munich, Germany; knut.brockow@tum.de

7 Department of Hematological Biology, Pitié-Salpêtrière Hospital, Pierre et Marie Curie University (UPMC), 75005 Paris, France; michel.arock@aphp.fr

8 Division of Allergy and Clinical Immunology, University of Michigan, Ann Arbor, MI 48106, USA; cemakin@med.umich.edu

9 Department of Internal Medicine I, Division of Hematology and Hemostaseology, Medical University of Vienna, 1090 Vienna, Austria; peter.valent@meduniwien.ac.at

10 Ludwig Boltzmann Institute for Hematology and Oncology, Medical University of Vienna, 1090 Vienna, Austria

* Correspondence: jromant@gumed.edu.pl; Tel.: +48-585844300

Abstract: Primary and secondary mast cell activation syndromes (MCAS) can occur in patients with mastocytosis. During the past few years our knowledge about the pathogenesis and diseasetriggering mechanisms in MCAS and mastocytosis have increased substantially. Whereas mastocytosis is characterized by an accumulation of neoplastic (clonal) mast cells (MC) in various organ systems, MCAS is defined by a massive and systemic activation of these cells. Mast cells are crucial effector cells in allergic diseases, thus their elevated number and activation can cause severe anaphylactic reactions and MCAS in patients with mastocytosis. However, these cells may also degranulate spontaneously or degranulate in response to non-allergic triggers leading to clinical symptoms. In mastocytosis patients, such symptoms may lead to the diagnosis of a primary MCAS. The diagnosis of a concomitant allergy in mastocytosis patients is challenging. In these patients, a mixed form (primary and secondary) of MCAS may be diagnosed. These patients may also suffer from life-threatening anaphylactic reactions when exposed to allergens. In these cases, the possibility of severe side effects of in vivo provocations can sometimes also limit diagnostic evaluations. In the current article, we discuss the diagnosis and management of patients suffering from mastocytosis and concomitant MCAS, with special emphasis on novel diagnostic tests and management, including allergen microarrays, recombinant allergen analysis, basophil activation tests, optimal prophylaxis, and specific therapies.

Keywords: mast cell; anaphylaxis; mastocytosis; hypersensitivity; MCAS 


\section{Introduction}

Mastocytosis is a group of rare hematologic neoplasms that can be divided into cutaneous mastocytosis (CM) and systemic mastocytosis (SM). In patients with SM, mast cell (MC) accumulations are found in extra-cutaneous organs, such as the bone marrow, spleen, liver, lymph nodes, or the gastrointestinal (GI) tract [1-4]. A number of different variants of SM have been defined, based on clinical and laboratory variables. These include indolent SM (ISM) and advanced forms of SM, such as aggressive SM (ASM), SM with an associated hematologic neoplasm (SM-AHN) or MC leukemia (MCL) $[1,4,5]$. The diagnosis of mastocytosis and its variants is established by applying WHO criteria [1,4]. Symptoms in SM may derive from organ damage caused by the local infiltration of neoplastic MC or from the mediators that are produced and released by neoplastic MC [6-8]. When the patient (i) is suffering from severe and typical MC mediator-induced symptoms, and (ii) the event is accompanied by a substantial elevation of serum tryptase levels above the individual's baseline (plus 20\% plus $2 \mathrm{ng} / \mathrm{mL}$ ), and (iii) a significant clinical response to MC-targeting drugs or MC mediator-targeting therapies can be documented, a MC activation syndrome (MCAS) may be diagnosed [2,7-12].

MC are well-known effector cells of allergic reactions. In IgE-mediated hypersensitivity reactions allergens cross-link specific IgE molecules that are bound to high affinity Fc\&RI on MC and thereby trigger degranulation [13,14]. Histamine is one of the clinically relevant mediators of MC that can cause typical symptoms of allergic reactions, such as urticaria, pruritus, rhinitis, bronchospasm, diarrhea, and/or hypotension [13-15]. However, other MC mediators, for instance certain leukotrienes or prostaglandins or various chemokines and proteases, may also contribute to the development of these symptoms in allergic reactions $[13,14,16]$. Apart from IgE-FceRI interaction and the downstream signaling pathways that are activated by FceRI cross-linking, MC can also be activated by other mechanisms and receptors expressed on the surface of MC. These include, among others, toll-like receptors, stem cell factor receptor $(\mathrm{KIT}=\mathrm{CD} 117)$, complement receptors, and surface $\mathrm{G}$ protein-coupled receptors, including MRGPRX2 [17]. Finally, MC in mastocytosis may be in a "hyperactive" state that may relate to genetic predispositions, such as hereditary alpha tryptasemia (HAT), and may contribute to the severity of allergic reactions. All these mechanisms may act together to cause degranulation of MC and thus lead to the symptoms of anaphylaxis.

In this review, we discuss mechanisms underlying the type and severity of mediatorrelated hypersensitivity reactions in patients with mastocytosis.

\section{Hymenoptera Venom-Induced Anaphylaxis in Mastocytosis}

It is estimated that about $56-94 \%$ of the adult population has been stung by a hymenoptera insect at least once during lifetime, depending on environmental conditions and the geographic region of residence [18]. Clinically relevant, systemic, reactions triggered by hymenoptera stings develop in otherwise healthy adults with a prevalence (percent of affected people at a certain time point) of $0.3-8.9 \%$ based on epidemiological studies performed in the last decade [19-21]. In patients with mastocytosis, the prevalence is much higher and has been reported to range between $22 \%$ and $49 \%$ in adults $[2,20,22]$ and between $6 \%$ and $9 \%$ in children $[2,20]$. Importantly in patients with SM and insect venom allergy (IVA) the risk of severe anaphylaxis is greater than in patients with IVA without a known MC disorder [21]. The predominant symptoms in these patients are vascular symptoms, including hypotension and syncope [23-25]. The association between anaphylaxis and cutaneous mastocytosis (urticaria pigmentosa) has been known for a long time. However, anaphylactic reactions also occur and are quite common in ISM patients with or without skin involvement [21,26]. Moreover, patients with ISM without skin lesions may be at a particular risk of anaphylaxis, with the highest risk of severe sting-induced anaphylaxis reported for male patients with SM without skin lesions and lower basal serum tryptase levels who represent a unique subgroup of ISM with a particularly low MC burden [27]. Many of these patients suffer from bone marrow mastocytosis, a special sub-variant of 
ISM. In patients with mastocytosis with tryptase levels ranging between $20.4 \mathrm{ug} / \mathrm{L}$ and $29.9 \mathrm{ug} / \mathrm{L}$ the prevalence of sting-induced anaphylaxis has been reported to be particularly high [28]. However, severe anaphylaxis and MCAS are also seen in patients with a high basal serum tryptase level. Together, anaphylaxis can occur in all forms of mastocytosis and does not typically or more frequently affect patients with advanced SM [23,29].

In the management of patients with anaphylaxis, it is of great importance to establish the correct diagnosis, to avoid triggering factors, and to provide optimal management and treatment. Based on the current guidelines all anaphylactic reactions in the medical history are a clear indication for a detailed allergy diagnosis. It is particularly important in case of insect venom allergy (IVA), as immunotherapy, the only causative treatment, should be initiated in these cases $[7,30]$. Diagnostic evaluations in patients with mastocytosis may be a clinical challenge. Because of the obvious risk, skin tests with standard insect venom extracts are only recommended in some of the centers. However, most centers recommend screens detecting hymenoptera-specific IgE, which should be performed at least 2-4 weeks after the reaction because of the possibility of a 'refractory state' after venom exposure $[23,30,31]$.

Measurements of specific IgE using venom extracts may reveal positive test results for multiple venoms, specific venom allergens, cross-reactive carbohydrates (CCD) or homologous, cross-reacting allergens present in various venoms. Results obtained with full venom extracts may sometimes be negative due to the under-representation of individual molecular allergens in the extract [31]. In several patients with SM, specific serum (s) IgE (detecting allergens) is not detectable probably because in these patients, most of the $\operatorname{IgE}$ is fixed to the MC surface membrane. Indeed when these patients undergo MC-reducing therapy, specific IgE may become detectable [32]. It is also worth noting that false-negative skin test results with Apis mellifera extract may be due to the lack of certain allergens in the diagnostic and therapeutic extract like Api m10 [33]. Some patients with mastocytosis have negative results in skin tests and in specific IgE detection assays. As mentioned before, this may be due to the fact that most of the IgE is fixed to the surface of MC in these cases. In addition, MC may be in a state of desensitization in SM. In line with this notion, negative results of skin tests and sIgE assays (results below $0.35 \mathrm{kUA} / \mathrm{L}$ ) are typically seen in patients with sting-induced anaphylaxis and an underlying mastocytosis.

Taking into account the high frequency of severe anaphylactic reactions and reports on fatal sting-induced anaphylaxis $[34,35]$ it is of great importance to use the appropriate sensitivity of $\operatorname{sigE}$ in patients with mastocytosis, which can be improved by lowering the threshold to $0.17 \mathrm{kUA} / \mathrm{L}$ without losing good specificity. It is suggested to confirm the IVA in patient with mastocytosis and provide venom immunotherapy (VIT) when skin test results are negative, but sIgE exceeds $0.17 \mathrm{kUA} / \mathrm{L}$ [35]. In some patients, it may be possible to determine the presence of sIgE against certain allergens and thus to confirm allergy using functional cellular assays, such as the basophil activation test (BAT) [7]. However, data of the utility of the BAT in patients with sting-induced anaphylaxis with skin tests and sIgE negative results vary according to the center and no robust studies testing this approach in CM or SM are available. In one previous report BAT was not reported to be useful in patients with mastocytosis and the negative results of standard tests [36]. In contrast, in other studies, BAT was found to yield positive results in sensitized mastocytosis patients with a sensitivity ranging between $81 \%$ and $87 \%$ [23,37].

The treatment of IVA in mastocytosis and MCAS patients is similar to patients without MC disorders. Therapies include allergen immunotherapy, histamine receptor-targeting drugs, and the equipment with an epinephrine emergency kit. Venom immunotherapy (VIT) is the only causative treatment. Although this treatment bears a certain risk of adverse events, the risk-benefit ratio is clearly in favor of VIT and therefore VIT should be administered in all sensitized patients with venom-induced anaphylaxis. In patients with severe anaphylaxis or a high risk to develop severe reactions, including those with mastocytosis and MCAS, VIT should be administered lifelong [7,38]. It is worth noting that in these patients, VIT is also considered to be a relatively safe and effective approach [38,39]. 
Therefore, recently published guidelines recommend the use of VIT in patients with SM and HVA $[21,38,40]$. The safety and the effectiveness of VIT were confirmed in patients with mastocytosis although slightly more adverse events were reported compared to patients without MC disorders [21,39]. According to the available reports, the incidence of side effects during VIT in mastocytosis patients ranges from around $18.9 \%$ [7] to $34 \%$ with the majority of cases $(73 \%)$ showing reactions in the induction phase and approximately $(27 \%)$ during the maintenance treatment [25]. These data are similar to the general population of IVA patients treated with VIT [40]. In both cohorts of patients, mastocytosis and non mastocytosis, a majority of the reactions are mild local side effects, and are more frequent to honey bee venom compared to vespid venom. Adrenaline was used to control severe anaphylaxis in $7.6 \%$ of the patients with mastocytosis, and 3-7\% in non-mastocytosis patients treated with VIT [40] Although the majority of all adverse events in patients with mastocytosis are mild, with local reactions accounting for $56 \%$ of these episodes, and $37.5 \%$ mild systemic reactions (without respiratory/cardiovascular symptoms), severe anaphylaxis may occur in up to $9 \%$ of all cases [25]. Generally vespid VIT was tolerated better (0-15\% of side-effects) than honeybee VIT in both groups of mastocytosis and MCAS and non-MC disorder cases [7,41,42]. Monitoring venom-specific IgG4 levels can reflect those patients who achieved tolerance during therapy [25]. Despite a more or less good protective effect in a majority of VIT-treated patients, every patient with mastocytosis with an anaphylactic episode in the history should carry at least 2 self-injectors of epinephrine even when on maintenance treatment with VIT. This recommendation is based on the persistent risk of systemic reactions to insect venoms during VIT [7].

\section{Inhalant Allergens}

Patients with SM may suffer from IgE-dependent allergies against various inhalant allergens and the incidence and prevalence may be the same when compared to patients without a MC disease. In population studies, the frequency of common atopic diseases in patients with mastocytosis ranged between $21 \%$ and $31 \%$, depending on the analyzed population [11,13-15]. An interesting study was made by Dollner et al. who performed comprehensive rhinologic assessment with specific IgE testing in 11 patients with SM reporting persistent nasal symptoms [43]. Only one of these patients turned out to have a confirmed documented allergy to grass pollen. As mentioned before, such negative test result may not necessarily exclude the presence of an (occult) allergy in all patients. However, it seems as if the prevalence of inhalant allergy in patients with mast cell disorders is similar to that in the general population.

The diagnosis of inhalant allergy is mainly based on skin prick tests and allergenspecific serum IgE. These tools are usually reliable and possess sensitivity and specificity of around $80 \%$ [44]. The gold standard-nasal provocation is usually troublesome and difficult to apply routinely in these patients. New in vitro tests, such as the BAT and mast cell activation test (MAT) may also assess cell activation [45,46]. However, no robust validation studies using these assays are available in patients with mastocytosis suffering from concomitant IgE-dependent inhalant allergy.

\section{Local Anesthetics}

In the older literature local anesthetics are sometimes mentioned as potential MC activators through $\operatorname{IgE}$ and non-IgE dependent reactions [47]. Up to 3\% of cases in the general population experience adverse reactions after local anesthesia [48,49]. Most, if not all, of these reactions are vasovagal in nature, whereas real allergic reactions seem to be rare ( $<1 \%$ of all adverse events). A type IV allergic mechanism appears to be more common than type I mechanism [48]. The vast majority of adverse events result from 'anxiety' reactions accompanying the surgical or dentist's procedure. Another possibility is the intravascular local anesthetic administration that can cause arrhythmias due to suppression of action potential generation in cardiac myocytes [48-50]. The fear of MC degranulation induced by local anesthetics origins partly from in vitro studies. Although at low concentration 
lidocaine decrease basophil and MC degranulation by lowering $\mathrm{Ca}^{2+}$ mobilization, at high the same drug may promote $\mathrm{MC}$ activation [51,52]. Matito et al. assessed the clinical risk of local anesthetics in patients with mastocytosis [47]. Among 515 administrations, only 4 were symptomatic (less than $1 \%$ ) and, when specifically reviewing epidural anesthesia, only 2 out of 76 patients had an adverse event $(2.5 \%)$. Overall, only one case of severe anaphylaxis after local anesthesia was reported in this study [47]. The authors concluded that the risk of allergic reactions and other side effects in patients with mastocytosis is relatively low and acceptable. Nevertheless, prophylactic premedication with antimediator-type therapy should be considered in all cases with mastocytosis, and should be applied strictly in all who report previous problems or a previous severe reaction to local anesthesia

\section{General Anesthetics}

The risk of anaphylaxis during general anesthesia in patients with MC disorders is difficult to assess. The incidence of perioperative anaphylaxis in patients with mastocytosis is estimated to be higher with $0.4 \%$ compared to that in the general population $(0.01 \%)$, although the study on patients with mastocytosis was relatively small, may have a selection bias and included only 3 anaphylactic cases in the cohort [47,53]. Most patients undergo surgery without complications, but in some studies anaphylaxis episodes in patients with mastocytosis tend to be more severe than in other patients [54-56]. Drugs such as morphine or codeine can degranulate $\mathrm{MC}$ in vitro, thus there was a discussion to avoid certain groups of drugs during general anesthesia, including opioids, muscle relaxants, or non-steroid antiinflammatory drugs [57-60]. However, this approach might lead to deprivation of proper perioperative analgesia or even needed surgical treatment for SM patients. Furthermore, some authors suggested that severe pain that is not relieved with proper opioid treatment might also cause MC activation $[61,62]$. Carter et al. reported that the risk of anaphylaxis may be significantly greater in major surgeries, patients with anaphylaxis history and in patients not receiving anti-mediator therapy including histamine receptor (HR)1-targeting and HR2-targeting drug [53]. It has also been reported that patients with mastocytosis who received benzodiazepines as premedication had a lower risk to develop anaphylaxis compared to patients who did not receive benzodiazepines to control stress reactions.

All in all, the use of general anesthesia is not contraindicated in mast cell disorders [53]. It is recommended to perform allergy tests before any procedure only in patients who had allergic reaction to anesthetics or anaphylaxis during anesthesia in the past. In case of inconclusive results, BAT can be performed as an additional test. It is worth noting that BAT has been particularly well validated in healthy population in detection of allergy towards neuromuscular blocking agents [63].

Apart from drugs used in general anesthesia, there is an emerging awareness of possible allergy to antiseptics that are used in perioperative period, particularly chlorhexidine [64]. It is commonly used before surgery and might cause anaphylaxis by IgE-related mechanisms. European Network of Drug Allergy suggests performing a combination of two test methods out of skin prick test, intracutaneous test and serum specific IgE upon patients with suspected chlorhexidine allergy [65]. In case of delayed reactions patch tests are recommended. Additionally, BAT, histamine release test and more recent MAT are being developed as supplementary tests, though they have not yet entered routine application [65-67].

Finally, it should be noted that the most important preparative step is to inform the surgery-team and the anesthesiologist that the patient is suffering from an underlying mast cell disorder and from concomitant allergies. In addition, all patients with mastocytosis or MCAS should receive prophylactic HR blockers, including HR1 and HR2-targeting drugs and those who are at high risk should also receive prophylactic glucocorticosteroids before surgery. 


\section{Non-Steroidal Anti-Inflammatory Drugs (NSAID)}

Aspirin hypersensitivity is quite prevalent in the general population $(0.6-5 \%)$ and might generate symptoms of MCA [68-70]. These reactions may also aggravate already existing allergic reactions [71]. Taking into account that $9-14 \%$ of patients with mastocytosis report severe symptom after taking aspirin or other NSAIDs, there is a reluctance to prescribe NSAIDs in this group of patients [72,73].

The real prevalence of idiosyncratic aspirin hypersensitivity in MC disorders probably does not differ from that in the general population. According to Hermans et al., only $2 \%$ of patients with mastocytosis have positive oral provocation test while other studies suggest that $4 \%$ of the patients present with hypersensitivity reactions to NSAIDs [74].

Skin lesions in MCA may result from $\mathrm{PGD}_{2}$ release [1]. Aspirin is a cyclooxygenase inhibitor that decreases $\mathrm{PGD}_{2}$ production in $\mathrm{MC}$ and thus might be an effective antimediator therapy in mastocytosis. However, the daily dose required to control symptoms of MCA in mastocytosis patients is rather high and may thus lead to severe side effects [75-77]. Therefore, aspirin is usually not recommended in patients with mastocytosis, unless the patient did not respond to conventional anti-mediator type drugs.

As a non-IgE-related reaction, the golden standard in NSAID and aspirin hypersensitivity diagnosis remain oral (preferred), intranasal and inhalation provocations [78,79]. Additionally, a few in vitro methods have been developed. These include (1) BAT, (2) sulfidoleucotrienes assay, (3) 15-HETE generation assay [80-82]. However, these methods are considered still under development and until now lack proper sensitivity, specificity and validation in larger groups of patients $[78,79]$. These assays may still be helpful in patients unable to undergo standard provocation protocols as in mastocytosis.

\section{Food Allergens}

Only a very few data on the clinical impact and prevalence of hypersensitivity reactions to food and related allergies in mastocytosis patients are available $[2,12,20,83,84]$.

Over half of the patients with MC disorders report symptoms which are supposedly triggered on consumption of food or beverages [85]. According to Jennings et al., 50.3\% of patients with mastocytosis report reactions to food. Another 23.2\% reported hypersensitivity to food products. So, in total $73.5 \%$ of patients symptoms are associated with diet. Most symptoms have been reported after eating fruits $(27 \%)$ and vegetables $(29 \%)$, especially tomatoes and citrus. Other perceived triggers included: dairy products $(26 \%)$, cereal grains $(24 \%)$, seafood $(24 \%)$, food additives $(21 \%)$ and spices $(19 \%)$. Interestingly, only $18 \%$ of patients indicated hypersensitivity to alcohol, despite the fact that alcohol metabolites have been reported to degranulate MCs directly in vitro, through non-specific activation [86].

In contrast to the numbers above, a recent study by Jarkvist et al. systematically investigated 204 patients with clonal MC disorders and revealed that the prevalence of food hypersensitivity in Swedish mastocytosis patients was only $20.6 \%$; i.e., comparable to the general population [83]. Interestingly, most hypersensitivity symptoms were limited to skin $(86 \%)$ and/or gastrointestinal tract $(45 \%)$, as only $2.5 \%$ of patients experienced anaphylaxis associated with food products (58). Furthermore, after thorough allergy workup including skin prick tests and specific IgE tests, only $6 \%$ of patients turned out to have an IgE-mediated food allergy $[83,87]$. These observations suggest that food-related symptoms reported by patients with $\mathrm{MC}$ disorders mostly result from either a wrong perception of the patients or are due to non-specific causes, whereas the actual prevalence of food allergies may be comparable to that found in the general population $[88,89]$. Thus, no general elimination diet for mastocytosis patients is recommended without confirmed clinically significant food hypersensitivity [83]. In addition, proper anti-mediator therapy might improve tolerance of certain food products, reducing MCA [1,7].

Microarray-based detection of allergy is a promising method in mastocytosis [32]. The prevalence of chip-positive patients is lower in mastocytosis due to lower levels of total $\mathrm{IgE}$ in mastocytosis patients, however the method may be a reliable screening approach 
for undetected allergies also in patients with mastocytosis [32]. The use of ISAC test in idiopathic anaphylaxis may contribute to the diagnosis in $20 \%$ of cases [90].

So far, no specific guidelines were established on food allergy diagnosis in mastocytosis. The recent paper by Vos et al. showed that the cut of level of $0.17 \mathrm{kUA} / \mathrm{L}$ sIgE increases sensitivity and specificity of the test in patients with mastocytosis. There is no data on that topic in food allergy jet [35]. Most of the following recommendations concern general population, however based on available publications $[11,12,20,83]$ and our experience, may be used in MCAS and mastocytosis cases.

\subsection{Nuts}

In case of patients reacting to nuts, it is important to distinguish whether they crossreact because of a primary birch pollen allergy or because there is an allergy to a genuine molecular allergen for the food. The most common major allergen in birch pollen, Bet v1, resembles specific allergens in hazelnut (Cor a 1), peanut (Ara h8) and soy (Gly m4). These proteins belong to the PR10 family, they are liable to heat and digestion. In such cases, the reactions are usually mild and limited to local reaction as in oral allergy syndrome. These patients would tolerate food in cooked form. However, if the patients present with anaphylactic reactions, we should analyze sIgE to the genuine food LTP (lipid transfer protein) and storage proteins. LTP allergens, such as in peanut (Ara h9), hazelnut (Cor a 8), walnut and pecan (Jug r3) are stable to heat and digestion. A LTP syndrome is associated with cross-allergy to stone fruits (peach-Pru p3, apple-Mal d3) and with allergy to Artemisia pollens. Storage proteins are main allergens of nuts and markers of primary sensitization. The main recombinant molecular sIgE for peanut (Ara h1, Ara h2, Ara h3), hazelnut (Cor a 9, Cor a 14), walnut and pecan (Jug r1), brazil nut (Ber e1), cashew nut and pistachio (Ana o3) are well-described. These proteins are stable to heat and digestion, associated with systemic reactions to cooked and raw food. Such patients should be consulted by allergologists and dietitians. In case of an anaphylactic reaction in mastocytosis and reaction to LTP and storage proteins the culprit and cross-reactive nuts should be avoided [91].

\subsection{Fish}

Patients with suspected fish allergy require an evaluation with skin prick test and detection of sIgE to most prevalent fish in their diet, such as cod, salmon, carp, tuna and cod parvalbumin (Gad c1-Baltic area, Gad m1-Atlantic area). Other proteins which may lead to anaphylaxis are enolase and aldolase. Parvalbumins are main fish allergens located in small muscles, stable to food processing, and can even become inhalant allergens. Thus, patients with true allergy may develop anaphylaxis due to the inhalation of fish allergen. In cases with negative sIgE to parvalbumin (Gad c1, Gad m1), sIgE to enolase (cod-Gad m2) and aldolase (Gad m3) should be measured. In case of the reaction to other fish i.e., tuna, salmon, hering, megrim, redfish, swordfish specific recombinant IgEs can be measured [91].

\subsection{Fruits and Vegetables}

Allergies to fruits and vegetables are most commonly secondary caused by crossreaction with pollen allergens (like birch pollen with its main allergen Bet v1) or less commonly true primary food allergy. In case of a clinical reaction, we can apply skin prick tests with commercial extract, native skin prick tests (prick to prick testing), sIgE to the whole allergen or recombinant sIgEs. The last method is a valuable tool in case of nsLTP (type 1) syndrome to fruits (Rosales-apple, peach, apricot, cherry, plum, pear, raspberry, strawberry, mulberry, Ericales-Kiwi, Zingiberales-banana, Sapindales-lemon, tangerine, sweet orange, Vitales-grape [91]. NsLTP protein is found in the tuber of the plant. Patients with positive recombinant sIgE to nsLTP homologues like Pru p3 in peach, Mal d 3 in apple should avoid both fresh and processed fruits. In contrast, those reacting primarily to tree pollen cross-reacting proteins like main birch allergen Bet v1 (Mal d1 in 
apples, Pru p3 in peach) or pollen profilin-related sensitization like birch allergen Bet v2 (peach Pru p3) should eliminate only fresh fruits [91]. Some fruits such as banana, avocado, chestnut, kiwifruit might cross react with latex [92]. The most prevalent vegetables causing anaphylactic reactions are celery, carrot, tomato, bell pepper. Cross reactions with grass pollen (celery) and birch and grass pollen (carrot) are frequent. Main allergens belong to PR-10 and nsLTP protein families [91].

\section{4. $E g g$}

Anaphylactic reactions are caused by the proteins located in white egg and they can cause inhalant allergy. The main protein-ovomucoid (Gal d1) is heat stable, causing patients to react to all egg-related food. Minor egg molecules like ovoalbumin (Gal d2), transferrin ( $\mathrm{Gal} \mathrm{d} 3$ ), egg lysozyme (Gal d4) are heat liable, thus patients would react only to raw and slightly heated egg.

\subsection{Wheat}

Allergy to wheat protein is quite common in patients in Northern Europe, and has recently been recognized as an emerging reason for anaphylaxis in adults [84]. Wheatdependent exercise-induced anaphylaxis (WDEIA) is the common form of omega-5-gliadin hypersensitivity. Severity of reaction depends on the co-factors like exercise, aspirin and alcohol. Specific IgE to Omega-5-gliadin (Tri a 19) is found in $50-80 \%$ of allergic patients, being marker of severity and persistence $[84,91]$.

\section{Hereditary Alpha Tryptasemia}

The severity of hypersensitivity reactions may be aggravated by several co-factors. Physical stimuli such as heat, stress, or exercise are commonly described by patients $[12,85,93]$. In addition, the genetic background may be a clinically relevant co-factor. In particular, a new condition has been described where patients present with (i) elevated basal serum tryptase levels, (ii) additional copies of the alpha tryptase gene (TPSAB1) and (iii) a higher risk to develop severe mediator-related symptoms [94-96]. This genetic trait found in $5 \%$ of the general population and is known as hereditary alpha tryptasemia (HAT) $[94,96,97]$. Some of these patients present with more severe symptoms of MC activation, including anaphylaxis to hymenoptera stings $[95,96]$. Hymenoptera venom allergy may also be more prevalent in mastocytosis patients with HAT than in cases without HAT (30.0\% vs. 9.9\%) [96]. HAT seems to be a predisposing condition and may be particularly relevant when present in patients with IgE-dependent allergies or SM. An interesting aspect is that the prevalence of HAT is particularly high in patients with SM. In fact, HAT is present in about $15-20 \%$ of all patients with SM [96]. There is a broad range of symptoms that have been associated with HAT. In a British cohort, the clinical findings were: urticaria/angioedema (51\%), abdominal pain $(43 \%)$, aches / pain (41\%), skin flushing $(41 \%)$, food intolerance $(39 \%)$, diarrhea $(36 \%)$, nausea/vomiting $(27 \%)$, behavioral issues $(24 \%)$, asthma $(20 \%)$, eczema $(19 \%)$, rhinitis $(19 \%)$, joint hypermobility (17\%), dizzy spells (16\%), constipation (13\%) [97]. However, the prevalence of HAT was similar in patients treated in allergy clinic and in the general population [97]. The diagnosis of HAT may be considered in patients with basal tryptase level is $\geq 10 \mathrm{ng} / \mathrm{mL}[95,97]$. In some patients with HAT the serum tryptase level is even lower $(8-10 \mathrm{ng} / \mathrm{mL})$. Diagnosis of HAT requires genetic analysis using ddPCR described by Lyons and colleagues [98].

\section{Management of Hypersensitivity Reactions in Patients with Mastocytosis}

Many patients with MC disorders present with mediator-related symptoms. These symptoms vary and range from mild and easily tolerable to life-threatening anaphylaxis. As mentioned above it is extremely difficult to distinguish allergic reactions from nonallergic hypersensitivities, taking to account similarity of symptoms and fact that certain triggers might cause both types of mechanisms $[1,3,99]$. The patients are advised to avoid all possible triggers. However, some triggers cannot be fully avoided (food, the need for 
anesthesia). Thus, a thorough allergy work-up (see paragraphs above and Table 1) in such cases is required to establish if certain drugs or food products are prohibited and to find a safe alternative. However, still hypersensitivity reaction may occur in these patients. Therefore, there is a consensus that all patients should receive chronic anti-mediator therapy including with HR1 and HR2 blockers and an emergency epinephrine kit $[99,100]$. Additional drugs might be added depending on organs involved. For example, proton pump inhibitors and cromolyn are considered in patients with gastrointestinal symptoms. Skin involvement might require higher doses of anti-HR1 and topical or systemic glucocorticosteroids. Some of these patients may benefit from high dose ( $>500 \mathrm{mg}$ daily) of aspirin but the risk of severe side effects and gastrointestinal problems is relatively high in these patients [75-77]. In case of anaphylaxis standard treatment with epinephrin should be used followed by glucocorticosteroids and HR1 blockers. Omalizumab is another effective agent that has been suggested for mastocytosis patients suffering from severe IgE-related allergic reactions [101-103]. Another potential approach is to apply midostaurin, a KIT and SYK-targeting multi-kinase inhibitor that blocks IgE-dependent mediator release from normal and neoplastic mast cells and basophils in vitro and in vivo [104-106]. In addition, midostaurin has been described to suppress mediator-related symptoms and to rapidly increase the quality of life in patients with SM [107]. However, so far, midostaurin can only be prescribed for patients with advanced SM.

Table 1. Test and methods used in hypersensitivity diagnosis in patients with mast cell disorders. SPT—Skin Prick Test; IDT—Intradermal Test; BAT—Basophil Activation Test; MAT—Mast cell Activation Test; NSAIDs-Non steroid anti-inflammatory drugs; AIT—Allergen Immunotherapy [7,23,30-32,44-46,53,63,64,66,67,79-82,90,91,108,109].

\begin{tabular}{|c|c|c|c|c|c|c|c|c|c|}
\hline $\begin{array}{l}\text { Allergen } \\
\text { Group }\end{array}$ & Challenge/Provocation & SPT & IDT & sIgE & $\begin{array}{l}\text { IgE Mi- } \\
\text { Croarray }\end{array}$ & BAT & $\begin{array}{l}\text { Other/Future } \\
\text { Perspectives }\end{array}$ & $\begin{array}{c}\text { Prevalence of } \\
\text { Hypersensitiv- } \\
\text { ity in Patients } \\
\text { with Mast Cell } \\
\text { Disorders }\end{array}$ & Management \\
\hline $\begin{array}{l}\text { Inhalant } \\
\text { allergens }\end{array}$ & + & + & - & + & + & + & MAT, $\mathrm{H} \alpha \mathrm{T}$ & No data & $\begin{array}{l}\text { Symptom } \\
\text { medications, } \\
\text { AIT }\end{array}$ \\
\hline Food allergens & + & + & - & + & + & + & $\mathrm{MAT}, \mathrm{H} \alpha \mathrm{T}$ & $20-75 \%$ & Avoidance \\
\hline $\begin{array}{l}\text { Hymenoptera } \\
\text { venom }\end{array}$ & $-{ }^{1}$ & + & + & + & + & + & $\mathrm{H} \alpha \mathrm{T}$ & $22-49 \%$ & AIT \\
\hline $\begin{array}{c}\text { Local } \\
\text { anesthetic }\end{array}$ & + & + & + & + & - & + & & $0.7 \%$ & Avoidance \\
\hline $\begin{array}{c}\text { General } \\
\text { anesthetic }\end{array}$ & - & + & + & + & - & + & MAT & & \\
\hline $\begin{array}{l}\text { Aspirin and } \\
\text { NSAIDs }\end{array}$ & + & - & - & - & - & + & $\begin{array}{l}\text { Sulfidoleucotrienes } \\
\text { assay, } 15 \text {-HETE } \\
\text { generation assay }\end{array}$ & & $\begin{array}{c}\text { Avoidance, } \\
\text { desensitization }\end{array}$ \\
\hline
\end{tabular}

Finally, depression and affective disorders usually require psychiatric consultation and administration of antidepressants [7]. Unfortunately, our current pharmacological and diagnostic possibilities are ineffective in about $10-20 \%$ of all MCAS patients and in about $10 \%$ of all mastocytosis patients [103]. These patients may benefit from the development of new drugs and new therapeutic approaches.

\section{Conclusions}

Patients with MC disorders often present with a variety of mediator-related symptoms that appear either spontaneously or after exposure to certain triggers, such as food, drugs, or insect venoms. The diagnosis of mastocytosis or MCAS in patients suffering from allergy or anaphylaxis may significantly change the management and treatment plan. Therefore, it is crucial to assess the etiology of allergic reactions, including IgE-dependent triggers of anaphylactic reactions as well as aggravating factors and co-morbidities. Diagnostic evaluations in patients suffering from mastocytosis, MCAS and allergic disorders is often 
a clinical challenge and may require a battery of diagnostic tools and assays, such as IgE and tryptase measurements, hematologic assessments, allergen microarrays, BAT/MAT, or HAT diagnostics. These multidisciplinary evaluations support the physician in arriving at a correct and final diagnosis and in establishing a robust management plan in each individual patient. Such individualized management should may in turn increase safety and the quality of life in patients with mastocytosis and MCAS.

Author Contributions: Conceptualization, J.R. and M.N.; writing—original draft preparation, J.R., M.N., A.G., M.G.-N., M.L.; writing—review and editing, T.G., B.N., K.B., M.A., C.A., P.V.; supervision, M.N., P.V.; funding acquisition, M.N., P.V., B.N. All authors have read and agreed to the published version of the manuscript.

Funding: Polish Ministry of Science and Higher Education-grant no ST 02-0141/07/231 and ST 02-0066/07/253. P.V. was supported by the Austrian Science Fund (FWF)—grants P32470, F4701-B20 and F4704-B20.

Institutional Review Board Statement: Not applicable.

Informed Consent Statement: Not applicable.

Data Availability Statement: No new data were created or analyzed in this study. Data sharing is not applicable to this article.

Conflicts of Interest: The authors declare no conflict of interest.

$\begin{array}{ll}\text { Abbreviations } \\ \text { BAT } & \text { Basophil activation test } \\ \text { CCD } & \text { Cross-reactive carbohydrates } \\ \text { CM } & \text { Cutaneous Mastocytosis } \\ \text { ISM } & \text { Indolent systemic mastocytosis } \\ \text { IVA } & \text { Insect venom allergy } \\ \text { MAT } & \text { Mast cell activation test } \\ \text { MC } & \text { Mast Cell } \\ \text { MCA } & \text { Mast Cell Activation } \\ \text { MCAS } & \text { Mast Cell Activation Syndrome } \\ \text { NSAIDs } & \text { Non-steroid anti-inflammatory drugs } \\ \text { PBL } & \text { Peripheral blood leucocytes } \\ \text { sBTL } & \text { Basal serum tryptase level } \\ \text { SM } & \text { Systemic Mastocytosis } \\ \text { VIT } & \text { Venom immunotherapy }\end{array}$

\section{References}

1. Valent, P.; Akin, C.; Metcalfe, D.D. Mastocytosis: 2016 updated WHO classification and novel emerging treatment concepts. Blood J. Am. Soc. Hematol. 2017, 129, 1420-1427. [CrossRef] [PubMed]

2. Brockow, K.; Jofer, C.; Behrendt, H.; Ring, J. Anaphylaxis in patients with mastocytosis: A study on history, clinical features and risk factors in 120 patients. Allergy 2008, 63, 226-232. [CrossRef] [PubMed]

3. Metcalfe, D.D. Mast cells and mastocytosis. Blood 2008, 112, 946-956. [CrossRef] [PubMed]

4. Valent, P.; Akin, C.; Sperr, W.R.; Escribano, L.; Arock, M.; Horny, H.-P.; Bennett, J.M.; Metcalfe, D.D. Aggressive systemic mastocytosis and related mast cell disorders: Current treatment options and proposed response criteria. Leuk. Res. 2003, 27, 635-641. [CrossRef]

5. Valent, P.; Horny, H.P.; Escribano, L.; Longley, B.J.; Li, C.Y.; Schwartz, L.B.; Marone, G.; Nuñez, R.; Akin, C.; Sotlar, K.; et al. Diagnostic criteria and classification of mastocytosis: A consensus proposal. Leuk. Res. 2001, 25, 603-625. [CrossRef]

6. Valent, P.; Sperr, W.R.; Schwartz, L.B.; Horny, H.-P. Diagnosis and classification of mast cell proliferative disorders: Delineation from immunologic diseases and non-mast cell hematopoietic neoplasms. J. Allergy Clin. Immunol. 2004, 114, 3-11. [CrossRef]

7. Romantowski, J.; Górska, A.; Lange, M.; Nedoszytko, B.; Gruchała-Niedoszytko, M.; Niedoszytko, M. How to diagnose mast cell activation syndrome? Practical considerations. Pol. Arch. Intern. Med. 2020, 130, 317-323. [CrossRef]

8. Akin, C.; Valent, P.; Metcalfe, D.D. Mast cell activation syndrome: Proposed diagnostic criteria. J. Allergy Clin. Immunol. 2010, 126, 1099-1104.e4. [CrossRef] 
9. Valent, P.; Akin, C.; Arock, M.; Brockow, K.; Butterfield, J.H.; Carter, M.C.; Castells, M.; Escribano, L.; Hartmann, K.; Lieberman, P.; et al. Definitions, Criteria and Global Classification of Mast Cell Disorders with Special Reference to Mast Cell Activation Syndromes: A Consensus Proposal. Int. Arch. Allergy Immunol. 2012, 157, 215-225. [CrossRef]

10. Valent, P.; Akin, C.; Bonadonna, P.; Hartmann, K.; Brockow, K.; Niedoszytko, M.; Nedoszytko, B.; Siebenhaar, F.; Sperr, W.R.; Elberink, J.N.G.O.; et al. Proposed Diagnostic Algorithm for Patients with Suspected Mast Cell Activation Syndrome. J. Allergy Clin. Immunol. Pract. 2019, 7, 1125-1133.e1. [CrossRef]

11. González-de-Olano, D.; Álvarez-Twose, I. Insights in Anaphylaxis and Clonal Mast Cell Disorders. Front. Immunol. 2017, 8, 792. [CrossRef]

12. Górska, A.; Niedoszytko, M.; Lange, M.; Chełmińska, M.; Nedoszytko, B.; Wasag, B.; Marek, J.; Gruchała-Niedoszytko, M.; Nowicki, R.; Jassem, E. Risk factors for anaphylaxis in patients with mastocytosis. Polskie Archiwum Medycyny Wewnetrznej 2015, 125, 46-53. [CrossRef] [PubMed]

13. Galli, S.J.; Tsai, M. IgE and mast cells in allergic disease. Nat. Med. 2012, 18, 693-704. [CrossRef]

14. Theoharides, T.C.; Valent, P.; Akin, C. Mast cells, mastocytosis, and related disorders. N. Engl. J. Med. 2015, 373, 163-172. [CrossRef] [PubMed]

15. Parsons, M.E.; Ganellin, C.R. Histamine and its receptors. Br. J. Pharmacol. 2006, 147 (Suppl. S1), S127-S135. [CrossRef]

16. Xie, H.; He, S.-H. Roles of histamine and its receptors in allergic and inflammatory bowel diseases. World J. Gastroenterol. 2005, 11, 2851-2857. [CrossRef]

17. Olivera, A.; Beaven, M.A.; Metcalfe, D.D. Mast cells signal their importance in health and disease. J. Allergy Clin. Immunol. 2018, 142, 381-393. [CrossRef]

18. Bilo, M.B.; Bonifazi, F. The natural history and epidemiology of insect venom allergy: Clinical implications. Clin. Exp. Allergy 2009, 39, 1467-1476. [CrossRef]

19. Bilò, M.B. Anaphylaxis caused by Hymenoptera stings: From epidemiology to treatment. Allergy 2011, 66, 35-37. [CrossRef]

20. de Olano, D.G.; Caballer, B.d.1.H.; Lopez, R.N.; Munoz, L.S.; Agustin, M.C.; Dieguez, M.C.; Twose, I.A.; Castells, M.C.; Mora, L.E. Prevalence of allergy and anaphylactic symptoms in 210 adult and pediatric patients with mastocytosis in Spain: A study of the Spanish network on mastocytosis (REMA). Clin. Exp. Allergy 2007, 37, 1547-1555. [CrossRef]

21. Bonadonna, P.; Lombardo, C.; Zanotti, R. Mastocytosis and allergic diseases. J. Investig. Allergol. Clin. Immunol. 2014, 24, 288-297. [PubMed]

22. Gulen, T.; Hagglund, H.; Dahlen, B.; Nilsson, G. High prevalence of anaphylaxis in patients with systemic mastocytosis-A singlecentre experience. Clin. Exp. Allergy 2014, 44, 121-129. [CrossRef] [PubMed]

23. Stoevesandt, J.; Sturm, G.J.; Bonadonna, P.; Elberink, J.N.G.O.; Trautmann, A. Risk factors and indicators of severe systemic insect sting reactions. Allergy 2020, 75, 535-545. [CrossRef] [PubMed]

24. Zanotti, R.; Lombardo, C.; Passalacqua, G.; Caimmi, C.; Bonifacio, M.; De Matteis, G.; Perbellini, O.; Rossini, M.; Schena, D.; Busa, M. Clonal mast cell disorders in patients with severe Hymenoptera venom allergy and normal serum tryptase levels. J. Allergy Clin. Immunol. 2015, 136, 135-139. [CrossRef] [PubMed]

25. Jarkvist, J.; Salehi, C.; Akin, C.; Gülen, T. Venom immunotherapy in patients with clonal mast cell disorders: IgG4 correlates with protection. Allergy 2020, 75, 169-177. [CrossRef]

26. Gülen, T.; Ljung, C.; Nilsson, G.; Akin, C. Risk factor analysis of anaphylactic reactions in patients with systemic mastocytosis. J. Allergy Clin. Immunol. Pract. 2017, 5, 1248-1255. [CrossRef]

27. Álvarez-Twose, I.; Zanotti, R.; González-de-Olano, D.; Bonadonna, P.; Vega, A.; Matito, A.; Sánchez-Muñoz, L.; Morgado, J.M.; Perbellini, O.; García-Montero, A. Nonaggressive systemic mastocytosis (SM) without skin lesions associated with insect-induced anaphylaxis shows unique features versus other indolent SM. J. Allergy Clin. Immunol. 2014, 133, 520-528. [CrossRef]

28. Van Anrooij, B.; van der Veer, E.; de Monchy, J.G.R.; van der Heide, S.; Kluin-Nelemans, J.C.; Vader, P.C.v.V.; van Doormaal, J.J.; Elberink, J.N.G.O. Higher mast cell load decreases the risk of Hymenoptera venom-induced anaphylaxis in patients with mastocytosis. J. Allergy Clin. Immunol. 2013, 132, 125-130. [CrossRef]

29. Niedoszytko, M.; Bruinenberg, M.; van Doormaal, J.J.; de Monchy, J.G.R.; Nedoszytko, B.; Koppelman, G.H.; Nawijn, M.C.; Wijmenga, C.; Jassem, E.; Elberink, J.N.G.O. Gene expression analysis predicts insect venom anaphylaxis in indolent systemic mastocytosis. Allergy 2011, 66, 648-657. [CrossRef]

30. Bonifazi, F.; Jutel, M.; Biló, B.M.; Birnbaum, J.; Muller, U. Prevention and treatment of hymenoptera venom allergy: Guidelines for clinical practice. Allergy 2005, 60, 1459-1470. [CrossRef]

31. Kleine-Tebbe, J.; Beyer, K.; Ebisawa, M. Molecular allergology user's guide. Pediatric Allergy Immunol. 2016, 27, 134-140.

32. Smiljkovic, D.; Kiss, R.; Lupinek, C.; Hoermann, G.; Greiner, G.; Witzeneder, N.; Krajnik, G.; Trautinger, F.; Vrtala, S.; Mittermann, I.; et al. Microarray-Based Detection of Allergen-Reactive IgE in Patients with Mastocytosis. J. Allergy Clin. Immunol. Pract. 2020, 8, 2761-2768.e16. [CrossRef] [PubMed]

33. Blank, S.; Seismann, H.; Michel, Y.; McIntyre, M.; Cifuentes, L.; Braren, I.; Grunwald, T.; Darsow, U.; Ring, J.; Bredehorst, R. Api m 10, a genuine A. mellifera venom allergen, is clinically relevant but underrepresented in therapeutic extracts. Allergy 2011, 66, 1322-1329. [CrossRef] [PubMed]

34. Dodd, N.J.; Bond, M.G. Fatal anaphylaxis in systemic mastocytosis. J. Clin. Pathol. 1979, 32, 31-34. [CrossRef] 
35. Vos, B.J.P.R.; van Anrooij, B.; van Doormaal, J.J.; Dubois, A.E.J.; Elberink, J.N.G.O. Fatal anaphylaxis to yellow jacket stings in mastocytosis: Options for identification and treatment of at-risk patients. J. Allergy Clin. Immunol. Pract. 2017, 5, 12641271. [CrossRef]

36. Bonadonna, P.; Zanotti, R.; Melioli, G.; Antonini, F.; Romano, I.; Lenzi, L.; Caruso, B.; Passalacqua, G. The role of basophil activation test in special populations with mastocytosis and reactions to hymenoptera sting. Allergy 2012, 67, 962-965. [CrossRef]

37. Bidad, K.; Nawijn, M.C.; van Oosterhout, A.J.M.; van der Heide, S.; Elberink, J.N.G.O. Basophil activation test in the diagnosis and monitoring of mastocytosis patients with wasp venom allergy on immunotherapy. Cytom. Part B: Clin. Cytom. 2014, 86, 183-190. [CrossRef]

38. Sturm, G.J.; Varga, E.-M.; Roberts, G.; Mosbech, H.; Bilò, M.B.; Akdis, C.A.; Antolín-Amérigo, D.; Cichocka-Jarosz, E.; Gawlik, R.; Jakob, T.; et al. EAACI guidelines on allergen immunotherapy: Hymenoptera venom allergy. Allergy 2018, 73, 744-764. [CrossRef]

39. De Olano, D.G.; Álvarez-Twose, I.; Esteban-López, M.I.; Sánchez-Muñoz, L.; de Durana, M.D.A.D.; Vega, A.; García-Montero, A.; González-Mancebo, E.; Belver, T.; Herrero-Gil, M.D. Safety and effectiveness of immunotherapy in patients with indolent systemic mastocytosis presenting with Hymenoptera venom anaphylaxis. J. Allergy Clin. Immunol. 2008, 121, 519-526. [CrossRef]

40. Niedoszytko, M.; de Monchy, J.; van Doormaal, J.J.; Jassem, E.; Elberink, J.N.G.O. Mastocytosis and insect venom allergy: Diagnosis, safety and efficacy of venom immunotherapy. Allergy 2009, 64, 1237-1245. [CrossRef]

41. Bilò, B.M.; Bonifazi, F. Hymenoptera venom immunotherapy. Immunotherapy 2011, 3, 229-246. [CrossRef] [PubMed]

42. Müller, U.; Helbling, A.; Hunziker, T.; Wüthrich, B.; Pécoud, A.; Gilardi, S.; Beretta, E.; Fasel, J.; Messerli, W.; Maurer, P. Mastocytosis and atopy: A study of 33 patients with urticaria pigmentosa. Allergy 1990, 45, 597-603. [CrossRef] [PubMed]

43. Dollner, R.; Taraldsrud, E.; Iversen, K.; Osnes, T.; Kristensen, B.; Kramer, M.F. Non-allergic, mastocytosis-associated rhinitis. Clin. Exp. Allergy 2013, 43, 406-412. [CrossRef] [PubMed]

44. Wise, S.K.; Lin, S.Y.; Toskala, E.; Orlandi, R.R.; Akdis, C.A.; Alt, J.A.; Azar, A.; Baroody, F.M.; Bachert, C.; Canonica, G.W.; et al. International Consensus Statement on Allergy and Rhinology: Allergic Rhinitis. Int. Forum Allergy Rhinol. 2018, 8, 108-352. [CrossRef] [PubMed]

45. Gómez, E.; Campo, P.; Rondón, C.; Barrionuevo, E.; Blanca-López, N.; Torres, M.J.; Herrera, R.; Galindo, L.; Mayorga, C.; Blanca, M. Role of the basophil activation test in the diagnosis of local allergic rhinitis. J. Allergy Clin. Immunol. 2013, 132, 975-976. [CrossRef]

46. Bahri, R.; Custovic, A.; Korosec, P.; Tsoumani, M.; Barron, M.; Wu, J.; Sayers, R.; Weimann, A.; Ruiz-Garcia, M.; Patel, N.; et al. Mast cell activation test in the diagnosis of allergic disease and anaphylaxis. J. Allergy Clin. Immunol. 2018, 142, 485-496.e16. [CrossRef]

47. Matito, A.; Morgado, J.M.; Sánchez-López, P.; Álvarez-Twose, I.; Sánchez-Muñoz, L.; Orfao, A.; Escribano, L. Management of Anesthesia in Adult and Pediatric Mastocytosis: A Study of the Spanish Network on Mastocytosis (REMA) Based on 726 Anesthetic Procedures. Int. Arch. Allergy Immunol. 2015, 167, 47-56. [CrossRef]

48. Boren, E.; Teuber, S.S.; Naguwa, S.M.; Gershwin, M.E. A critical review of local anesthetic sensitivity. Clin. Rev. Allergy Immunol. 2007, 32, 119-127. [CrossRef]

49. Grzanka, A.; Wasilewska, I.; Śliwczyńska, M.; Misiołek, H. Hypersensitivity to local anesthetics. Anaesthesiol. Intensive Ther. 2016, 48, 128-134. [CrossRef]

50. Gunera-Saad, N.; Guillot, I.; Cousin, F.; Philips, K.; Bessard, A.; Vincent, L.; Nicolas, J.-F. [Immediate reactions to local anesthetics: Diagnostic and therapeutic procedures]. Ann. Dermatol. Venereol. 2007, 134, 333-336. [CrossRef]

51. Yanagi, H.; Sankawa, H.; Saito, H.; Iikura, Y. Effect of lidocaine on histamine release and Ca ${ }^{2+}$ mobilization from mast cells and basophils. Acta Anaesthesiol. Scand. 1996, 40, 1138-1144. [CrossRef] [PubMed]

52. Johnson, H.G.; Miller, M.D. Inhibition of histamine release and ionophore-induced calcium flux in rat mast cells by lidocaine and chlorpromazine. Agents Actions 1979, 9, 239-243. [CrossRef] [PubMed]

53. Carter, M.C.; Metcalfe, D.D.; Matito, A.; Escribano, L.; Butterfield, J.H.; Schwartz, L.B.; Bonadonna, P.; Zanotti, R.; Triggiani, M.; Castells, M.; et al. Adverse reactions to drugs and biologics in patients with clonal mast cell disorders: A Work Group Report of the Mast Cells Disorder Committee, American Academy of Allergy, Asthma \& Immunology. J. Allergy Clin. Immunol. 2019, 143, 880-893. [CrossRef]

54. Bonadonna, P.; Pagani, M.; Aberer, W.; Bilo, M.B.; Brockow, K.; Elberink, H.O.; Garvey, L.; Mosbech, H.; Romano, A.; Zanotti, R.; et al. Drug hypersensitivity in clonal mast cell disorders: ENDA/EAACI position paper. Allergy 2015, 70, 755-763. [CrossRef] [PubMed]

55. Ahmad, N.; Evans, P.; Lloyd-Thomas, A.R. Anesthesia in children with mastocytosis-A case based review. Pediatric Anesth. 2009, 19, 97-107. [CrossRef]

56. Carter, M.C.; Uzzaman, A.; Scott, L.M.; Metcalfe, D.D.; Quezado, Z. Pediatric mastocytosis: Routine anesthetic management for a complex disease. Anesth. Analg. 2008, 107, 422-427. [CrossRef]

57. Nguyen, J.; Luk, K.; Vang, D.; Soto, W.; Vincent, L.; Robiner, S.; Saavedra, R.; Li, Y.; Gupta, P.; Gupta, K.; et al. Morphine stimulates cancer progression and mast cell activation and impairs survival in transgenic mice with breast cancer. Br. J. Anaesth. 2014, 113, i4-i13. [CrossRef]

58. Sheen, C.H.; Schleimer, R.P.; Kulka, M. Codeine induces human mast cell chemokine and cytokine production: Involvement of G-protein activation. Allergy 2007, 62, 532-538. [CrossRef]

59. Steinke, J.W.; Negri, J.; Liu, L.; Payne, S.C.; Borish, L. Aspirin activation of eosinophils and mast cells: Implications in the pathogenesis of aspirin-exacerbated respiratory disease. J. Immunol. 2014, 193, 41-47. [CrossRef] 
60. Galvão, V.R.; Giavina-Bianchi, P.; Castells, M. Perioperative Anaphylaxis. Curr. Allergy Asthma Rep. 2014, 14, 452. [CrossRef]

61. Dewachter, P.; Castells, M.C.; Hepner, D.L.; Mouton-Faivre, C. Perioperative Management of Patients with Mastocytosis. Anesthesiology 2014, 120, 753-759. [CrossRef] [PubMed]

62. Czarny, J.H.; Lange, M.; Niedoszytko, M.B.; Kwiecińska, B.; Górska, A.; Ługowska-Umer, H.; Sikorska, M.; Nowicki, R. Nadwrażliwość i alergia na leki u chorych na mastocytozę. Dermatology Rev. 2017, 104, 22-30. [CrossRef]

63. Abuaf, N.; Rajoely, B.; Ghazouani, E.; Levy, D.A.; Pecquet, C.; Chabane, H.; Leynadier, F. Validation of a flow cytometric assay detecting in vitro basophil activation for the diagnosis of muscle relaxant allergy. J. Allergy Clin. Immunol. 1999, 104, 411-418. [CrossRef]

64. Beaudouin, E.; Kanny, G.; Morisset, M.; Renaudin, J.M.; Mertes, M.; Laxenaire, M.C.; Mouton, C.; Jacson, F.; Moneret-Vautrin, D.A. Immediate hypersensitivity to chlorhexidine: Literature review. Eur. Ann. Allergy Clin. Immunol. 2004, $36,123$.

65. Chiewchalermsri, C.; Sompornrattanaphan, M.; Wongsa, C.; Thongngarm, T. Chlorhexidine Allergy: Current Challenges and Future Prospects. J. Asthma Allergy 2020, 13, 127-133. [CrossRef]

66. Song, W.-J.; Chang, Y.-S. Recent applications of basophil activation tests in the diagnosis of drug hypersensitivity. Asia Pac. Allergy 2013, 3, 266-280. [CrossRef]

67. Elst, J.; van der Poorten, M.-L.M.; Faber, M.A.; Van Gasse, A.L.; Garvey, L.H.; Bridts, C.H.; De Puysseleyr, L.P.; Mertens, C.; Hagendorens, M.M.; Sabato, V.; et al. Mast cell activation test in chlorhexidine allergy: A proof of concept. Br. J. Anaesth. 2020, 125, 970-975. [CrossRef]

68. Lumry, W.R.; Curd, J.G.; Zeiger, R.S.; Pleskow, W.W.; Stevenson, D.D. Aspirin sensitive rhinosinusitis: The clinical syndrome and effects of aspirin administration. J. Allergy Clin. Immunol. 1983, 71, 580-587. [CrossRef]

69. Pleskow, W.W.; Stevenson, D.D.; Mathison, D.A.; Simon, R.A.; Schatz, M.; Zeiger, R.S. Aspirin-sensitive rhinosinusitis/asthma: Spectrum of adverse reactions to aspirin. J. Allergy Clin. Immunol. 1983, 71, 574-579. [CrossRef]

70. Grattan, C.E.H. Aspirin sensitivity and urticaria. Clin. Exp. Dermatol. 2003, 28, 123-127. [CrossRef]

71. Pfeffer, I.; Fischer, J.; Biedermann, T. Acetylsalicylic acid dependent anaphylaxis to carrots in a patient with mastocytosis. J. Ger. Soc. Dermatol. 2011, 9, 230. [CrossRef] [PubMed]

72. Sanchez-Matas, I.; Matito-Bernechea, A.; de Olano, G.; Alvarez-Twose, I.; Sanchez-Munoz, L.; Caballer, B.d.1.H.; Escribano, L. Prevalence of hypersensitivity reactions to nonsteroidal anti-inflamatory drugs in 212 patients with mastocytosis in Spain: 1513. Allergy 2009, 64, 574-575.

73. Kasper, L.; Sladek, K.; Duplaga, M.; Bochenek, G.; Liebhart, J.; Gladysz, U.; Malolepszy, J.; Szczeklik, A. Prevalence of asthma with aspirin hypersensitivity in the adult population of Poland. Allergy 2003, 58, 1064-1066. [CrossRef] [PubMed]

74. Hermans, M.A.W.; van der Vet, S.Q.A.; van Hagen, P.M.; van Wijk, R.G.; van Daele, P.L.A. Low frequency of acetyl salicylic acid hypersensitivity in mastocytosis: The results of a double-blind, placebo-controlled challenge study. Allergy 2018, 73, $2055-2062$. [CrossRef] [PubMed]

75. Morrow, J.D.; Oates, J.A.; Roberts, L.J., II; Zackert, W.E.; Mitchell, T.A.; Lazarus, G.; Guzzo, C. Increased Formation of Thromboxane In Vivo in Humans with Mastocytosis. J. Investig. Dermatol. 1999, 113, 93-97. [CrossRef]

76. Crawhall, J.C.; Wilkinson, R.D. Systemic mastocytosis: Management of an unusual case with histamine (H1 and H2) antagonists and cyclooxygenase inhibition. Clin. Investig. Med. 1987, 10, 1-4.

77. Horny, H.-P.; Reiter, A.; Sotlar, K.; Valent, P. Mastocytosis. In Encyclopedia of Pathology; Springer: Cham, Switzerland, 2018; pp. 1-11.

78. Kowalski, M.L.; Agache, I.; Bavbek, S.; Bakirtas, A.; Blanca, M.; Bochenek, G.; Bonini, M.; Heffler, E.; Klimek, L.; Laidlaw, T.M.; et al. Diagnosis and management of NSAID—Exacerbated Respiratory Disease (N-ERD)—A EAACI position paper. Allergy 2019, 74, 28-39. [CrossRef]

79. Kowalski, M.L.; Makowska, J.S.; Blanca, M.; Bavbek, S.; Bochenek, G.; Bousquet, J.; Bousquet, P.; Celik, G.; Demoly, P.; Gomes, E.R.; et al. Hypersensitivity to nonsteroidal anti-inflammatory drugs (NSAIDs)—Classification, diagnosis and management: Review of the EAACI/ENDA\# and GA2LEN/HANNA. Allergy 2011, 66, 818-829. [CrossRef]

80. Çelik, G.; Bavbek, S.; Misirligil, Z.; Melli, M. Release of cysteinyl leukotrienes with aspirin stimulation and the effect of prostaglandin E2 on this release from peripheral blood leucocytes in aspirin-induced asthmatic patients. Clin. Exp. Allergy 2001, 31, 1615-1622. [CrossRef]

81. Jedrzejczak-Czechowicz, M.; Lewandowska-Polak, A.; Bienkiewicz, B.; Kowalski, M.L. Involvement of 15-lipoxygenase and prostaglandin EP receptors in aspirin-triggered 15-hydroxyeicosatetraenoic acid generation in aspirin-sensitive asthmatics. Clin Exp. Allergy 2008, 38, 1108-1116. [CrossRef]

82. Gamboa, P.; Sanz, M.L.; Caballero, M.R.; Urrutia, I.; Antepara, I.; Esparza, R.; De Weck, A.L. The flow-cytometric determination of basophil activation induced by aspirin and other non-steroidal anti-inflammatory drugs (NSAIDs) is useful for in vitro diagnosis of the NSAID hypersensitivity syndrome. Clin. Exp. Allergy 2004, 34, 1448-1457. [CrossRef]

83. Jarkvist, J.; Brockow, K.; Gülen, T. Low Frequency of IgE-Mediated Food Hypersensitivity in Mastocytosis. J. Allergy Clin. Immunol. Pract. 2020, 8, 3093-3101. [CrossRef] [PubMed]

84. Oropeza, A.R.; Bindslev-Jensen, C.; Broesby-Olsen, S.; Kristensen, T.; Møller, M.B.; Vestergaard, H.; Kjaer, H.F.; Halken, S.; Lassen, A.; Mortz, C.G. Patterns of anaphylaxis after diagnostic workup: A follow-up study of 226 patients with suspected anaphylaxis. Allergy 2017, 72, 1944-1952. [CrossRef] [PubMed] 
85. Jennings, S.; Russell, N.; Jennings, B.; Slee, V.; Sterling, L.; Castells, M.; Valent, P.; Akin, C. The Mastocytosis Society Survey on Mast Cell Disorders: Patient Experiences and Perceptions. J. Allergy Clin. Immunol. Pract. 2014, 2, 70-76. [CrossRef] [PubMed]

86. Matsuse, H. Mechanism and management of alcohol-induced asthma. Nihon Arukoru Yakubutsu Igakkai Zasshi-Jpn. J. Alcohol Stud. Drug Depend. 2016, 51, 214-220.

87. Gell, P.G.H.; Coombs, R.R.A. The classification of allergic reactions underlying diseases. In Clinical Aspects of Immunology; F. A. Davis Company: Philadelphia, PA, USA, 1963.

88. Muraro, A.; Werfel, T.; Hoffmann-Sommergruber, K.; Roberts, G.; Beyer, K.; Bindslev-Jensen, C.; Cardona, V.; Dubois, A.; duToit, G.; Eigenmann, P.; et al. EAACI food allergy and anaphylaxis guidelines: Diagnosis and management of food allergy. Allergy 2014, 69, 1008-1025. [CrossRef] [PubMed]

89. Gupta, R.S.; Warren, C.M.; Smith, B.M.; Jiang, J.; Blumenstock, J.A.; Davis, M.M.; Schleimer, R.P.; Nadeau, K.C. Prevalence and Severity of Food Allergies Among US Adults. JAMA Netw. Open 2019, 2, e185630. [CrossRef] [PubMed]

90. Heaps, A.; Carter, S.; Selwood, C.; Moody, M.; Unsworth, J.; Deacock, S.; Sumar, N.; Bansal, A.; Hayman, G.; El-Shanawany, T.; et al. The utility of the ISAC allergen array in the investigation of idiopathic anaphylaxis. Clin. Exp. Immunol. 2014, 177, 483-490. [CrossRef]

91. Matricardi, P.M.; Kleine-Tebbe, J.; Hoffmann, H.J.; Valenta, R.; Hilger, C.; Hofmaier, S.; Aalberse, R.C.; Agache, I.; Asero, R.; Ballmer-Weber, B.; et al. EAACI Molecular Allergology User's Guide. Pediatr. Allergy Immunol. 2016, 27 (Suppl. S2), 1-250. [CrossRef]

92. Chełmińska, M.; Specjalski, K.; Różyło, A.; Kołakowska, A.; Jassem, E. Differentiating of cross-reactions in patients with latex allergy with the use of ISAC test. Adv. Dermatol. Allergol. 2016, 33, 120-127. [CrossRef]

93. Jennings, S.V.; Slee, V.M.; Zack, R.M.; Verstovsek, S.; George, T.I.; Shi, H.; Lee, P.; Castells, M.C. Patient Perceptions in Mast Cell Disorders. Immunol. Allergy Clin. N. Am. 2018, 38, 505-525. [CrossRef] [PubMed]

94. Lyons, J.J. Hereditary alpha tryptasemia: Genotyping and associated clinical features. Immunol. Allergy Clin. 2018, 38, 483-495. [CrossRef] [PubMed]

95. O'Connell, M.P.; Lyons, J.J. Hymenoptera venom-induced anaphylaxis and hereditary alpha-tryptasemia. Curr. Opin. Allergy Clin. Immunol. 2020, 20, 431-437.

96. Greiner, G.; Sprinzl, B.; Górska, A.; Ratzinger, F.; Gurbisz, M.; Witzeneder, N.; Schmetterer, K.G.; Gisslinger, B.; Uyanik, G.; Hadzijusufovic, E.; et al. Hereditary alpha tryptasemia is a valid genetic biomarker for severe mediator-related symptoms in mastocytosis. Blood 2020. [CrossRef] [PubMed]

97. Robey, R.C.; Wilcock, A.; Bonin, H.; Beaman, G.; Myers, B.; Grattan, C.; Briggs, T.A.; Arkwright, P.D. Hereditary AlphaTryptasemia: UK Prevalence and variability in disease expression. J. Allergy Clin. Immunol. Pract. 2020, 8, 3549-3556. [CrossRef]

98. Lyons, J.J.; Yu, X.; Hughes, J.D.; Le, Q.T.; Jamil, A.; Bai, Y.; Ho, N.; Zhao, M.; Liu, Y.; O'Connell, M.P. Elevated basal serum tryptase identifies a multisystem disorder associated with increased TPSAB1 copy number. Nat. Genet. 2016, 48, 1564-1569. [CrossRef]

99. Valent, P.; Akin, C.; Gleixner, K.V.; Sperr, W.R.; Reiter, A.; Arock, M.; Triggiani, M. Multidisciplinary Challenges in Mastocytosis and How to Address with Personalized Medicine Approaches. Int. J. Mol. Sci. 2019, 20, 2976. [CrossRef]

100. Valent, P.; Akin, C.; Escribano, L.; Fodinger, M.; Hartmann, K.; Brockow, K.; Castells, M.; Sperr, W.R.; Kluin-Nelemans, H.C.; Hamdy, N.A.T; et al. Standards and standardization in mastocytosis: Consensus statements on diagnostics, treatment recommendations and response criteria. Eur. J. Clin. Investig. 2007, 37, 435-453. [CrossRef]

101. Carter, M.C.; Robyn, J.A.; Bressler, P.B.; Walker, J.C.; Shapiro, G.G.; Metcalfe, D.D. Omalizumab for the treatment of unprovoked anaphylaxis in patients with systemic mastocytosis. J. Allergy Clin. Immunol. 2007, 119, 1550. [CrossRef]

102. Broesby-Olsen, S.; Vestergaard, H.; Mortz, C.G.; Jensen, B.; Havelund, T.; Hermann, A.P.; Siebenhaar, F.; Møller, M.B.; Kristensen, T.K.; Bindslev-Jensen, C. Omalizumab prevents anaphylaxis and improves symptoms in systemic mastocytosis: Efficacy and safety observations. Allergy 2018, 73, 230-238. [CrossRef]

103. Le, M.; Miedzybrodzki, B.; Olynych, T.; Chapdelaine, H.; Ben-Shoshan, M. Natural history and treatment of cutaneous and systemic mastocytosis. Postgrad. Med. 2017, 129, 896-901. [CrossRef] [PubMed]

104. Valent, P.; Akin, C.; Hartmann, K.; George, T.I.; Sotlar, K.; Peter, B.; Gleixner, K.V.; Blatt, K.; Sperr, W.R.; Manley, P.W. Midostaurin: A magic bullet that blocks mast cell expansion and activation. Ann. Oncol. 2017, 28, 2367-2376. [CrossRef] [PubMed]

105. Peter, B.; Winter, G.E.; Blatt, K.; Bennett, K.L.; Stefanzl, G.; Rix, U.; Eisenwort, G.; Hadzijusufovic, E.; Gridling, M.; Dutreix, C. Target interaction profiling of midostaurin and its metabolites in neoplastic mast cells predicts distinct effects on activation and growth. Leukemia 2016, 30, 464-472. [CrossRef] [PubMed]

106. Krauth, M.; Mirkina, I.; Herrmann, H.; Baumgartner, C.; Kneidinger, M.; Valent, P. Midostaurin (PKC412) inhibits immunoglobulin Edependent activation and mediator release in human blood basophils and mast cells. Clin. Exp. Allergy 2009, 39, 1711-1720. [CrossRef]

107. Hartmann, K.; Gotlib, J.; Akin, C.; Hermine, O.; Awan, F.T.; Hexner, E.; Mauro, M.J.; Menssen, H.D.; Redhu, S.; Knoll, S. Midostaurin improves quality of life and mediator-related symptoms in advanced systemic mastocytosis. J. Allergy Clin. Immunol. 2020, 146, 356-366.e4. [CrossRef]

108. Nel, L.; Eren, E. Peri-operative anaphylaxis. Br. J. Clin. Pharmacol. 2011, 71, 647-658. [CrossRef]

109. Eberlein, B.; Wigand, S.; Lewald, H.; Kochs, E.; Ring, J.; Biedermann, T.; Darsow, U. Utility of basophil activation testing to assess perioperative anaphylactic reactions in real-world practice. Immun. Inflamm. Dis. 2017, 5, 416-420. [CrossRef] 